Meta

Journal des traducteurs

Translators' Journal

\title{
Parliamentary Interpreting in Malaysia: A Case Study
}

\section{Noraini Ibrahim}

Volume 54, numéro 2, juin 2009

URI : https://id.erudit.org/iderudit/037686ar

DOI : https://doi.org/10.7202/037686ar

Aller au sommaire du numéro

\section{Éditeur(s)}

Les Presses de l'Université de Montréal

ISSN

0026-0452 (imprimé)

1492-1421 (numérique)

Découvrir la revue

Citer cette note

Ibrahim, N. (2009). Parliamentary Interpreting in Malaysia: A Case Study. Meta, 54(2), 357-369. https://doi.org/10.7202/037686ar

\section{Résumé de l'article}

Le présent article traite de la situation actuelle de l'interprétation parlementaire en Malaisie. Il fait état d'une recherche centrée sur les caractéristiques de ce type d'interprétation, l'aptitude des interprètes parlementaires, leur formation universitaire, leur rémunération ainsi que leurs possibilités de promotion. Il prend aussi en compte certains aspects cruciaux de la profession, à savoir l'idéalisation dont elle fait l'objet, la formation continue, la relation entre les centres de formation, l'ambiance de travail, la nécessité d'informer le public grâce à la mise en oeuvre d'un réseau d'associations professionnelles, l'établissement d'un code de déontologie et l'émergence du professionnalisme chez les interprètes. L'auteur fait une série de propositions visant à améliorer l'exercice de cette profession, ce qui pourrait contribuer à la professionnalisation de l'interprétation non seulement au Parlement de Malaisie, mais aussi dans le reste du pays.
Ce document est protégé par la loi sur le droit d'auteur. L'utilisation des services d’Érudit (y compris la reproduction) est assujettie à sa politique d'utilisation que vous pouvez consulter en ligne.

https://apropos.erudit.org/fr/usagers/politique-dutilisation/ 


\title{
Parliamentary Interpreting in Malaysia: A Case Study
}

\author{
NORAINI IBRAHIM \\ University Science of Malaysia, Penang, Malaysia \\ noni_is@yahoo.com
}

\begin{abstract}
RÉSUMÉ
Le présent article traite de la situation actuelle de l'interprétation parlementaire en Malaisie. Il fait état d'une recherche centrée sur les caractéristiques de ce type d'interprétation, l'aptitude des interprètes parlementaires, leur formation universitaire, leur rémunération ainsi que leurs possibilités de promotion. II prend aussi en compte certains aspects cruciaux de la profession, à savoir l'idéalisation dont elle fait l'objet, la formation continue, la relation entre les centres de formation, l'ambiance de travail, la nécessité d'informer le public grâce à la mise en œuvre d'un réseau d'associations professionnelles, l'établissement d'un code de déontologie et l'émergence du professionnalisme chez les interprètes. L'auteur fait une série de propositions visant à améliorer l'exercice de cette profession, ce qui pourrait contribuer à la professionnalisation de l'interprétation non seulement au Parlement de Malaisie, mais aussi dans le reste du pays.
\end{abstract}

\begin{abstract}
This article seeks to describe the current scenario of parliamentary interpreting in Malaysia by studying the interpreters' work nature, aptitude and qualifications as well as remuneration and promotional opportunity. It also highlights the important aspects of the profession such as job mystification, training and continuing education, the connection between the training centres and the professional environment, the need to educate the public through the establishment of professional associations, and the implementation of an ethics code as well as the sense of professionalism among the interpreters. The author also proposes ways to improve the situation which would contribute to the professionalisation of interpreting in the Malaysian Parliament particularly and in Malaysia in general.
\end{abstract}

\section{MOTS-CLÉS/KEYWORDS}

interprétation parlementaire, interprétation de conférence, Malaisie, conditions de travail chez les interprètes, professionnalisation

parliamentary interpreting, conference interpreting, Malaysia, interpreters' working conditions, professionalisation

\section{Introduction}

With the wave of globalisation sweeping the world, communication is made easier as technology in communications advances. Linguistic and cultural differences no longer pose an obstacle in the pursuit of knowledge and technology exchange, and one activity that contributes to such transfers is conference interpreting, i.e., inter- 
national conferences and congresses. In the West, the development of the profession is well documented, for example in a few recent works by Baigorri-Jalón (2000, 2003, $2004,2005)$ on the history of conference interpreting, Waliczek (2003) on interpreting in Poland, or Angelelli (2004) on interpreters in Canada, Mexico, and the United States. In the East, interpreting activities are more actively researched in countries such as China and Japan, for example in articles and books written by Lung and Li (2005), Dawrant and Jiang (2001), and Komatsu (2003). However, in smaller countries such as Malaysia, no such study has ever been conducted.

This paper offers a description of the current scenario in parliamentary interpreting in Malaysia as part of preliminary research on conference interpreting in Malaysia (Ibrahim 2005). Before describing the parliamentary-interpreting scenario, we will briefly look into issues of professionalisation in interpreting and the system of parliament in Malaysia. After discussing the research objectives and methodology, the scenario is described under seven subheadings, which are: interpreter aptitudes and qualifications, the interpreter, interpreter job description, interpreter workload, remuneration and promotion, training and exposure, and interpreter working environment. This is followed by discussion and conclusion, which include suggestions on improving the situation of parliamentary interpreting in Malaysia.

\section{Issues of professionalisation in interpreting}

According to Schmitz (1988: 269), the root of the problem in the professionalisation of interpreting is that there is a lack of knowledge by the people at large on what interpreters do. Public ignorance leads to another problem that is a lack of control in terms of admission into the field. He further expresses his concern below:

Anyone can decide to use the title [translator/interpreter], however dim their consciousness may be of the intellectual equipment required for the jobs [...]. If someone designs a building he does not call himself an architect unless he is qualified to do so [...] And yet anyone who thinks he knows a foreign language and can therefore translate, and who feels like earning a living that way full-time or part-time, can put an ad in the paper without more ado claiming to be a translator and interpreter (Schmitz 1988: 273-274).

Waliczek (2003: 53) and Tseng (1992: 68) share the same idea as Schmitz, viewing this problem as a lack of exclusivity of a systematic body of knowledge in the profession, which allows anyone who thinks he or she knows and is familiar with a foreign language to interpret and translate and call himself or herself a translator or an interpreter. Professionalisation would be the answer to this problem. Schmitz (1988: 274), Tseng (1992: 81), Mikkelson (1999), Hall (1968; quoted in Underwood 2001) and Houle (1980; quoted in NVAA 2002) agree that a professional association and professional code of ethics are sine qua non for professionalisation. In the field of conference interpreting, The International Association of Conference Interpreters (Association Internationale des Interprètes de Conférence -AIIC) is the only international professional body with a membership of more than 2600 conference interpreters in over 80 countries. AIIC promotes the profession of conference interpretation in the interest of both users and practitioners by setting high standards, providing guidelines for working conditions that comply with the International Standard ISO, promoting sound training practices and fostering professional ethics (AIIC Website). 
Besides the establishment of a professional association and implementation of an ethics code, a high degree of specialisation or a broad general knowledge would enable translators or interpreters to settle into their work with ease, in turn improving the quality of work that they produce (Schmitz 1988: 271). Such specialisation could be achieved through continuing professional education as pointed out by Schubert (1988: 336) and Pöchhacker (2004: 189). Schubert (1988: 336) proposes the establishment of a university institute (an advisory centre) which coordinates the professionalisation efforts by offering courses of its own based on approved postgraduate training programmes designed for the whole translating community and to be attended by all groups of translators and interpreters. Waliczek (2003: 52) writes that "the most acute problem of the interpretation market is that there are few training institutions." Pöchhacker (2004: 189) further underlines the importance of meta-level training in the profession. These are educational efforts that include continuing not only education for practising interpreters, training for teachers of interpreting, and user education, but also training in research skills. These are "important complementary pathways" in achieving professionalisation and better professional standards.

\section{Conference interpreting and parliamentary interpreting}

Gile (1989) suggested ten prototypes of conference interpreting whereby parliamentary interpreting and interpreting for congresses or conferences come under the umbrella of conference interpreting. However, according to Pöchhacker's typology (2004: 16), conference interpreting is a type of interpreting that "takes place within a particular format of interaction ('conference'). It is often set in an international environment...(and) has spread far beyond multilateral diplomacy to virtually any field of activity involving coordination and exchange across linguistic boundaries." He adds that this situation differs from the "local" market of conference interpreting, which takes place primarily between English and the national language, for example parliamentary interpreting in certain countries. Hence, the important element that differentiates conference interpreting and parliamentary interpreting is the "international environment" that exists in conference interpreting and the "local environment" in parliamentary interpreting.

\section{The parliament of Malaysia}

Malaysia is a federation of thirteen states, founded in 1963, which adopted a Parliamentary Democracy with a Constitutional Monarchy. The government consists of three components: legislative, executive and judiciary. His Royal Highness (Yang di Pertuan Agung) is the paramount ruler. The legislature, or the Parliament of Malaysia, is divided into three parts: His Royal Highness, The Senate (Dewan Negara) and The House of Representatives (Dewan Rakyat). There are 70 members in the Senate while the House of Representatives has 219 elected members (Parliament's Website).

Due to the multi-ethnicity of Malaysia, members of the Senate and the House of Representatives are comprised of individuals from different ethnic and linguistic backgrounds. The official language of the Parliament is the Malay language, with simultaneous interpreting into English, which is available for the members and 
visitors. Interpreting into Malay is provided when there are foreign visitors who deliver their speeches in English. Simultaneous interpreting is performed in both Houses. When this practice was first introduced, there was only a single booth with a single microphone. However, with the upgrading of the Parliament buildings in recent years, the interpreting booths have become better equipped (Wong 1991: 9).

\section{Conference interpreting in Malaysia}

The Malaysian National Institute of Translation Berhad (Institut Terjemahan Negara Malaysia Berhad - ITNM) was established on $14^{\text {th }}$ September 1993, to provide the infrastructure and facilitate the creation of the translation and interpreting industry in Malaysia. Being a public limited company, the Malaysian government, under the Ministry of Finance (Incorporated) owns its share capital. However, the Ministry of Education supervises its administration (ITNM's Website).

From the academic perspectives, Universiti Sains Malaysia in Penang is the only university that offers a Bachelor of Arts in Translation and Interpreting (B.A. Hons. Terjemahan dan Interpretasi - BATI). The programme was established in 1992/1993, offering introductory interpreting courses: Sight Interpretation, Consecutive Interpretation of Technical and Non-technical Texts, Simultaneous Interpretation of Technical and Non-technical Texts (BATI 2004/2005 Student Guide). From professional training perspectives, ITNM offers an interpreting course to the general public, and is available on demand. The 30 -hour course is conducted twice a year (ITNM's Website).

Despite the establishment of ITNM as a governing body and Universiti Sains Malaysia's Bachelor of Arts in Translation and Interpreting programme, the current situation of interpreting in Malaysia does not differ markedly from what was depicted by Schmitz (1988), Tseng (1992) and Waliczek (2003), as described by Ibrahim:

Unfortunately language service providers here (in Malaysia) operate in a chaotic and unregulated market, in which anyone who claims to be an interpreter/translator can set up as one. Unlike the medical and legal fields, where entry, continued membership and behaviour of members are governed, language service providers lack such regulation. There is a gnawing concern that translators and interpreters can, and may, distort meaning, whether deliberately or inadvertently. Thus the crucial requirement for a code of ethics. But this cannot happen unless and until the machinery for professional training is put in place. The Malaysian interpreter virtually receives no training. (Ibrahim 2004)

\section{Research objectives}

The main objective of this study is to describe the current scenario of parliamentary interpreting in Malaysia. Thus, it focuses on the nature of interpreter work which includes a description of the job scope, working conditions, background training, working languages, specialized areas, professional training, remuneration, problems and constraints, and such issues as the role of professional associations, the involvement of training centres, admission into the profession, a professional ethics code among practitioners and its implementation, and continuing education for interpreters. 


\section{Methodology}

\subsection{Subjects}

The interpreting task is undertaken by a team of in-house simultaneous interpreters which is placed under the Simultaneous Interpretation Section of the House of Parliament and Legislative Division. The team is comprised of three in-house simultaneous interpreters. There are two female interpreters (X1, X3) and one male interpreter (X2) working as permanent interpreters for both the House of Lords and the House of Representatives.

\subsection{Data Collection}

The methods used in this case study include a review of documents as well as observation and survey. Five documents were reviewed in this study: interpreter's desk file, duty schedule of the interpreter, schedule of translation of the Order Paper, interpreter's job advertisement and the website of the Malaysian Parliament. The working conditions of the simultaneous interpreters were directly observed during a training session wherein the interpreters translated Malay into English. The interpreting booths in the House of Representatives were photographed. An unstructured interview was conducted with the three interpreters (a focus-group interview), where they were allowed to express their thoughts and concerns without being rigidly guided by the researcher. They were then asked to fill out a questionnaire with the researcher present for any clarification needed.

The questionnaire consisted of two main categories. The categories of general and academic background, working background, job scope, as well as constraints and problems faced by the interpreters were used to analyse the process by which interpreters work, i.e., their work nature. On the other hand, categories such as the role of a professional association and needs for training were meant for analysing the relationship between the structure (the interpreters, the employer) and the process (the nature of the work). Questions included both open-ended and close-ended types.

\section{Results}

This section discusses the results from the data collected. For the purpose of clarity, they will be discussed in seven separate subheadings.

\subsection{Interpreter aptitude and qualifications}

The job advertisement of simultaneous interpreters (Public Service Commission of Malaysia's Website) provides information on requirements for appointments, covering for example the aptitudes and qualifications required by the employer, (Malaysia Parliament), starting salary, and the job description for the simultaneous interpreter. The requirements for the interpreter's post are as follows:

1) Bachelor's Degree from local higher institutions of learning that are recognized by the government or other similar recognized qualifications, or

2) Bachelor's Degree with Honours from local higher institutions of learning that are recognized by the government or other recognized qualifications of its equivalent. 
3) Ability to speak, read and write as well as translate simultaneously from Malay into Arabic, English, or French or other relevant languages and vice versa.

4) A credit in Malay language (including a pass in the Oral Test) for the Malaysian Certificate Examination or other qualifications which are recognized to be its equivalent by the government.

\subsection{The interpreter}

The data of the present study show that all three of the interpreters have university qualifications (Table 1). Two of them (X1 and X3) hold Bachelor of Arts in English while interpreter X2 has a Diploma in Mass Communications. Interpreter X3 has a minor in Computer Science. They graduated from Universiti Kebangsaan Malaysia, Universiti Putera Malaysia and Institut Teknologi MARA Shah Alam. Interpreter X1 has been employed for nine years and interpreter X2 has eleven years of experience. Interpreter X3 joined the team more than two years ago. None of them has been formally trained as interpreters or translators, even though interpreter X2 took one paper of Translation Techniques during his Diploma studies. They translate only from Malay into English. None of them belong to an association of professional translators or interpreters. X3 never worked as freelance interpreter or translator, while X1 rarely takes such work. Only X2 often provides freelance interpreting and translating services outside the Parliament (Table 2).

TABLE 1

Simultaneous interpreters general and academic background

\begin{tabular}{|c|c|c|c|c|c|}
\hline Interpreters & Gender & Age & Qualifications & $\begin{array}{c}\text { Graduating } \\
\text { Year }\end{array}$ & $\begin{array}{c}\text { University / } \\
\text { Institute }\end{array}$ \\
\hline X1 & Female & 33 & BA (Eng) & 1996 & UKM \\
\hline X2 & Male & 52 & Diploma & 1990 & ITM \\
\hline X3 & Female & 26 & BA (Eng) & 2002 & UPM \\
\hline
\end{tabular}

TABLE 2

Simultaneous interpreters working background

\begin{tabular}{|c|c|c|c|c|c|c|}
\hline Interpreters & $\begin{array}{c}\text { Length of } \\
\text { Service } \\
\text { (Year since) }\end{array}$ & $\begin{array}{c}\text { Approximate } \\
\text { Remuneration } \\
\text { (RM)/(USD) }\end{array}$ & Training & $\begin{array}{c}\text { Working } \\
\text { Languages }\end{array}$ & $\begin{array}{c}\text { Freelance } \\
\text { Translator / } \\
\text { Interpreter }\end{array}$ & $\begin{array}{c}\text { Association } \\
\text { Membership }\end{array}$ \\
\hline X1 & $9(1997)$ & $3000 / 789.5$ & No & Malay-Eng & Rarely & No \\
\hline X2 & $11(1995)$ & $2570 / 676.3$ & 1 paper & Malay-Eng & Often & No \\
\hline X3 & $2(2004)$ & $1600 / 421.0$ & No & Malay-Eng & Never & No \\
\hline
\end{tabular}

\subsection{Interpreter job description}

The interpreters report to the Head Assistant Secretary of Hall Management Section. The interpreter's desk file (Fail Meja Jurubahasa Serentak 2002) and the job advertisement (Public Service Commission of Malaysia's Website) provide a list of tasks that should be performed by the interpreters which are:

1) To render good-quality simultaneous interpreting during meetings of the Senate and the House of Representatives. 
2) To provide a good-quality written translation of Order Papers for the House of Representatives.

3) To be in charge of the Translation Rooms of the Senate and the House of Representatives.

4) To escort visits to the Parliament and provide simultaneous interpretation service to foreign delegates especially the official guests of the State who are visiting to see how both Houses of the Malaysian Parliament function.

5) To act as a secretariat of international conferences organized by the Parliament of Malaysia

6) To act as a co-secretary to the Committee of Government's Official Events for the opening ceremony of the Parliament.

7) To prepare the itinerary book for the Opening Ceremony of the Parliament.

8) To prepare the itinerary book for the Parliament's Opening Ceremony Administration.

9) To prepare Opening Ceremony's invitation cards.

10) To prepare printed materials such as: International Conference handbook, International Conference invitation cards.

11) To edit the questions for the Senate.

12) To give briefings and to carry out tasks related to Commonwealth Parliamentary Association (CPA), Inter-Parliamentary Union (IPU) and ASEAN Inter-Parliamentary Organization (AIPO).

13) To perform other tasks as directed by the Head of Department, such as translating internal documents and speeches, act as ushers during the Opening Ceremony of the Parliament, provide liaison interpreting when there are foreign visitors visiting the Speaker of the Parliament, perform simultaneous interpreting in the Annual Budget session, using texts which are provided fifteen minutes prior to the Budget presentation.

\subsection{Interpreter workload}

The Duty Schedule of Simultaneous Interpreter and the Schedule of Translation of Order Paper show the interpreters' workload.

The Duty Schedule of Simultaneous Interpreter shows that the interpreters take 30-minute turns, but sometimes this is not the case as they prefer to finish interpreting for one speaker, even if it takes more than 30 minutes, so that the other interpreter starts interpreting for another speaker. Each interpreter is allocated 2 to 2.5 hours a day for interpreting, depending on the turn taking. Sometimes the sessions are prolonged if important issues arise in the discussion. Self-initiated training sessions are undertaken individually during the House of Representative sessions. The duration of these sessions is 100 working days per year. According to the Schedule of Translation of Order Paper, the number of questions appearing in the Order Papers are divided almost equally among the three interpreters.

\subsection{Remuneration and promotion}

The starting salary of the simultaneous interpreter is RM1627.11 (approximately US\$428.20), which is placed at Grade N41: P1T3 of the public service remuneration scale for graduates with Bachelor's Degree with Honours. For those who are graduates with Bachelor's Degree, the starting salary is RM 1469.81 (approximately US\$386.80), at Grade N41: P1T1 (Jadual Gaji 2002). 
For promotion in terms of pay-scale, the interpreters are required to sit for an examination which consists of four components: i) General Paper (topics about general knowledge); ii) Specific Paper (topics about the Parliament); iii) Translation, and iv) Interpreting. The translation and interpretation are evaluated by an internal examiner who is a non-expert in the field.

\subsection{Training and exposure}

All three simultaneous interpreters expressed the need for training, especially in interpreting and translating techniques, as they did not know or were not sure whether the techniques they adopt in carrying out their tasks are correct. Besides translation and interpreting training, they also expressed their need to learn a third language. The job advertisement states that an applicant should be "able to speak, read and write as well as translate simultaneously from Malay language into Arabic or English or French or other relevant languages and vice-versa." However, these working languages are unnecessary in the Parliament (except for English) and none of the interpreters can speak either Arabic or French. They also stated the need to improve their linguistic capabilities so as to provide better service, other than the necessity to increase their general knowledge, as issues discussed in the Parliament cover a very wide range of subject matter, including politics, religion, technology, and medicine. None of them is specialized in any specific area but a knowledge of politics proved essentiel since the issues discussed in Parliament are politically oriented.

Even though it was stated in the job description, the desk file, and the job advertisement that the interpreters are to act as co-secretariat to Commonwealth Parliamentary Association (CPA), Inter-Parliamentary Union (IPU) and ASEAN Inter-Parliamentary Organization (AIPO), none of them have performed such tasks.

The interpreters indicated that lack of motivation is caused by routine work, the absence of promotional opportunity, as well as a lack of recognition and appreciation by the employee. They feel that it is unjustified that the job evaluation, for the purpose of salary increase, is done by a non-expert.

\subsection{Interpreting booth}

The Translation Room is equipped with telephone, a computer with internet connection, and two interpreting booths. The two booths are separated by a wall and a glass window. The interpreting booth is located in the southwest corner of the Hall. The booths are separated by a glass window which the interpreters claim poses problems of communication between the interpreters if they need to confer with one another. The projection from the screen placed in the hall cannot be clearly seen from inside the booths.

\section{Discussion}

First of all we look at admission into the profession. The basic requirement to become a parliamentary interpreter is a Bachelor's degree. They are placed under the professional category in the government service. However, no prior knowledge of interpreting is required. The fact that interpreting is done from Malay into English, two of the interpreters recruited have Bachelor's Degree in English and one with a Diploma 
in English, with no translation or interpreting background. The interpreters graduated from universities that do not offer translation and interpreting courses. This lack of translation and interpreting training background makes them self-taught simultaneous interpreters. Even though Universiti Sains Malaysia produces graduates of Translation and Interpretation with its Bachelor of Arts in Translation and Interpretation programme, the public (the employer, in this case) might not be aware of this resource. This situation reflects the lack of connection between universities as training centres and the Translation and Interpretation market in Malaysia. Universities, as discussed in Section 3.0, are venues for coordinating all the efforts to raise the professional standard of interpreters.

This, as mentioned by Harris and Sherwood (1978, quoted in Pöchhacker 2004: 22 ), is "translating done in everyday circumstances by people who have had no special training for it." In this case, even parliamentary simultaneous interpreters who are linked to an established organization were recruited without prior training or knowledge of translation and interpreting, having background only in the English language. Even after their recruitment, no interpreter training was offered. This phenomenon supports the fact mentioned by Schmitz (1988: 269), "that there are far more people who DO interpreting than who ARE interpreters." The public (in this case, the employer) is still ignorant about the real essence of the interpreting profession. This issue also highlights the lack of exclusivity in the profession, as mentioned by Zubaidah (2004) regarding the interpreting scenario in Malaysia.

As pointed out in Section 3.0, professional associations and the implementation of a professional code of ethics are two very important elements of a profession. However, the interpreters in the Malaysian Parliament do not belong to any professional translators or interpreters association. No professional code of ethics is imposed on them, not even by the employer. The establishment of The Malaysian National Institute of Translation as an official organization in the Malaysian translation and interpreting industry (Section 3.0) does not appear to play a major role in terms of professionalising the field via training and continuing education, which are deemed necessary tools in upgrading the interpreting services in Malaysia.

In terms of problems and constraints, their routine work affects their motivation level. The 'ghost-role' that they play in their job and the lack of job mystification make them feel unappreciated by their employers. This matter should not be taken lightly as this could affect their work quality. Exposing them to more challenging tasks, as stated in their job description, and a better working scheme that allows mobility in the profession and promotional opportunity (for example, Interpreter, Higher Interpreter, Senior Interpreter and Chief Interpreter) would help them acquire the skills and recognition that they lack. It is also evident from the interpreters' remuneration (Table 2) and the salary scale (Section 7.5) that there is a strong connection between qualifications and salary. Interpreter X2 has eleven years of experience but due to his lower qualifications than interpreter X1, his salary is lower despite his having more experience than interpreter X1. This again supports the importance of training and continuing education for the practising interpreters as it would give them the opportunity to improve their official qualifications and to increase their pay.

In terms of their working conditions, the booths are situated in such a way that the interpreters do not have a clear view of the delegates who are seated on the west 
side of the Hall. The screen that is placed in the Hall does not really help the interpreters as the projection onto the screen cannot be seen very clearly from inside the booths. This situation does not comply with the International Standard ISO 2603 of the fixed interpreting booth which states that,

They [the booths] shall be raised no further above the floor of the hall than is necessary for a clear view of all proceedings in the hall, i.e. all participants, lecturers, the chairman, etc., as well as all visual aids (projection screen, etc.). The view from the booths into the hall shall not be obstructed by persons standing (ISO 2603, 2002).

However the aspect of sound-proofing between interpreting booths complies with the ISO 2603, despite the concern expressed by the interpreters about the lack of communication between the two interpreting booths should they need to refer to one another during the interpreting session (Section 7.7). Another important observation concerns turn-taking. The turn-taking proposed in the Duty Schedule of Simultaneous Interpreters is 30 minutes. However, interpreters prefer to finish interpreting a whole speech even though the 30 minutes might have elapsed before the debate finishes. Moser-Mercer, Korac and Künzli, conducting a pilot study on effects of prolonged turns in simultaneous interpreting on conference interpreters, concluded that,

[the results] provided evidence for the negative effect prolonged turns (those lasting longer than 30 minutes) have on the quality of an interpreter's output and on his attitude towards the task. [...] Interpreters do not seem to be sufficiently aware of the decline in quality that occurs in the course of prolonged turn so as to quit when given the opportunity to do so (Moser-Mercer, Korac and Künzli 1998: 62).

Due to the lack of theoretical knowledge of interpreting, the parliamentary interpreters adopt a method that is most convenient and efficient for them via selftaught sessions.

They also express their concern over the wide range of topics that have to be dealt with in the parliamentary sessions. Again, the answer to this problem is continuing education for the practising interpreters, which in turn would improve the quality of their work. They are probably already doing a good job through self-training, but may lack the confidence that they actually are good interpreters. With training, they would gain the assurance that they are producing good-quality work. As a result, they would win respect from the clients (in this case, not just the parliamentary delegates but also recognition from the employer). With such respect, mystification of the profession (Section 3.0) is possible. Such job mystification aids the professionalisation process.

Finally, the findings of this case study reflect the three types of professionals in Translation and Interpreting, as proposed by Bell (2000, quoted in Ibrahim 2003: 87). Firstly, there are pseudo-professional interpreters who are designated as professional category in the government service and are required to hold a Bachelor's Degree recognized by the government. Secondly, there are para-professionals who have acquired the skills through years of experience even though they lack professional training. Thirdly, there are proto-professionals because the interpreters feel a strong need for training even though there is no professional association, no code of ethics, and no in-house job training. 


\section{Conclusion}

The interpreting profession in Malaysia still faces problems similar to those experienced by counterparts many years ago: lack of regulation, inadequate training, easy admission into the profession, no professional association, no professional code of ethics, and lack of public education on what interpreting and interpreters really are. These issues are not limited to the Malaysian freelance market but also occur in such established government organisations as the Malaysia Parliament. There are similar situations in government offices in China where the in-house interpreters are graduates with foreign-language degrees, the majority of whom are self-taught interpreters with no specific training (Dawrant and Jiang 2001).

Simultaneous interpreters in the Parliament of Malaysia play the 'ghost-role' and their invisibility and routine work affect their level of motivation. However, a sense of professionalism is evident as they show a very high level of concern in the quality of their work and their desire for continuing professional education. A stricter access into the profession should be exercised, permitting only candidates with previous experience or training in interpreting. This would be accomplished by concatenating or linking together employers and training centres, for instance the Malaysian National Institute of Translation Berhad (Institut Terjemahan Negara Malaysia ITNM) as well as Universiti Sains Malaysia being the sole university offering a Bachelor of Arts in Translation and Interpreting in Malaysia. The training centres could act as a resource centre where employers or interpreting service providers could source out individuals with relevant background to work with them.

This joint intellectual and professional effort would eventually aid the continuing education of the interpreters especially those who are not Translation and Interpretation graduates. Such collaboration would also provide a beneficial link between professional interpreters, academicians, and researchers in creating a mutual platform where exchange of knowledge and experience could take place. Subsequently this would lead to the establishment of a conference interpreters association and professional code of ethics which are considered essential to a profession. The professional association acts as a mediator between practitioners of the field and the public (end users, employers, service providers), educating the public on what interpreting and interpreters are all about, guarding the clients' rights via the implementation of a professional code of ethics while at the same protecting the interest of the interpreters.

The synergy of all relevant players in the field (interpreters, employers, universities, training centres, professional association, the public) could generate an enhanced combined effect that would act as a catalyst in overcoming the problem of exclusivity and job mystification faced in the field and accelerate its growth. This would greatly contribute to the professionalisation of interpreting in Malaysia.

\section{REFERENCES}

AIIC (2005): Introducing AIIC. Visited on January $30^{\text {th }}, 2009$, <http://aiic.net/ViewPage.cfm/ article 8>.

ANGelelli, Claudia (2004): Revisiting the Interpreter's Role. A study of conference, court, and medical interpreters in Canada, Mexico, and the United States. Amsterdam: John Benjamins. 
BAIGORRI-JALÓN, Jesús (2000): La interpretación de conferencias: el nacimiento de una profesión. De París a Nuremberg. Granada: Comares.

BAIgORRI-JALÓN, Jesús (2003): La investigación en historia de la interpretación de conferencias. In: Emilio Ortega Arjonilla, ed. Panorama actual de la investigación en traducción e interpretación. Granada: Editorial Atrio, 1:341-356.

BAIgORRI-JALón, Jesús (2004): Interpreters at the United Nations: A History. Salamanca: Ediciones Universidad Salamanca.

BAIgORRI-JALÓN, Jesús (2005): Conference Interpreting in the First International Labor Conference (Washington, D.C.,1919). Meta. 50(3):987-996.

Dawrant, Andrew and Jiang, Hong (2001): Conference Interpreting in Mainland China. Communicate! [Online] July-August 2001. Visited on January $30^{\text {th }}, 2009,<$ http://www.aiic. net/ViewPage.cfm/article252.htm>.

Fail Meja Jurubahasa Serentak N.3. (2002): Parlimen Malaysia, Kuala Lumpur.

Gile, Daniel (1989): Les flux d'information dans les reunions interlinguistiques et l'interprétation de conference: premières observations. Meta. 34(4):649-660.

ISO 2603--Booths for simultaneous interpretation. 1998. AIIC. Visited on February $2^{\text {nd }}, 2009$, $<$ http://www.aiic.net/community/attachments/ViewAttachment.cfm/a417p587-674. pdf?\&filename $=a 417$ p587-674.pdf\&page_id=587>.

Jadual Gaji Baru dan Sifir Pemindahan Gaji bagi Perkhidmatan Pentadbiran dan Sokongan Pengurusan Profesional (2002): Visited on January $30^{\text {th }}, 2009$, <http://www.jpa.gov.my/ pekeliling/pp02/bil04/Klasifikasi-N.pdf>.

Komatsu, Taro (2003): Tsuyaku no eigo nihongo (English and Japanese in Interpreting). Tokyo: Bunshunshinsho.

Lung, Rachel and LI, Donghui (2005): Interpreters as Historians in China. Meta. 50(3):9971009.

Mikkelson, H. (1999): The Professionalisation of Community Interpreting. Visited on February ${ }^{\text {nd }}$, 2009, <http://www.acebo.com/ papers/profslzn.htm>.

Moser-Mercer, Barbara, Künzli, Alexander and Korac, Marina (1998): Prolonged turns in interpreting: Effects on quality, physiological and psychological stress. Interpreting. 3(5):47-65.

National Victim Assistance Academy Textbook (NVAA) (2002): Visited on February $2^{\text {nd }} 2009$, $<$ http://www.ojp.gov/ovc/assist/nvaa2002/chapter20.html>.

Ibra him, Noraini (2005): Professionalisation of Interpreting in Malaysia: A Case Study of Parliamentary Interpreting in Malaysia. Unpublished pre-doctoral thesis. Faculty of Translation and Interpretation, University of Granada.

IBRAHIM, Zubaidah (2003): Court interpreting in Malaysia in relation to language planning and policy. Unpublished doctoral thesis. Fakulti Bahasa dan Linguistik. Universiti Malaya.

Ibrahim, Zubaidah (2004): Say You, Say Me. Focus, New Sunday Times. October 31 ${ }^{\text {st }}, 2004$.

PöchHACKer, Franz (2004): Introducing Interpreting Studies. London: Routledge.

Schmitz, Manfred (1988): Statutory regulation of the practice of the profession and the use of the title "Translator/Interpreter." In: Nekeman, Paul, ed. Translation, Our Future. La Traduction, Notre Avenir. XIth World Congress FIT Proceedings. The Netherlands: Euroterm Maastricht, 269-275.

SChubert, Manfred (1988): Towards an integrated training system for interpreters and translators. In: Nekeman, Paul, ed. Translation, Our Future. La Traduction, Notre Avenir. XIth World Congress FIT Proceedings. The Netherlands: Euroterm Maastricht, 335-337.

The Malaysian National Institute of Translation (2005): Visited on January $30^{\text {th }}, 2009$, <http:/ www.itnm.com.my/about.php>.

Tseng, Joseph (1992): Interpreting as an Emerging Profession in Taiwan - A Sociological Model. Unpublished Master's dissertation, Fu Jen Catholic University, Taiwan.

Underwood, Thomas (2001): The Professionalisation of Victim Assistance. An Exploratory Study of Attitudinal Dimensions and Factors. Visited on February $2^{\text {nd }}, 2009,<$ http://www. washburn.edu/ce/jcvvs/research/professionalization/full.shtml>. 
WaliczeK, B. (2003): Quality interpreting in Poland: Facing local challenges. In: Collados Aís, Ángela, Fernández SÁnchez, María Manuela. and Gile, Daniel, eds. La evaluación de la calidad en interpretación: investigación. Granada: Comares, 47-57.

Website of The Parliament of Malaysia. Visited on February $2^{\text {nd }}$, 2009, <http://www.parlimen. gov.my/eng-pengenalan-lblakng.htm>.

Wong, Fook Khoon (1991): Interpretation in Malaysia - Yesterday, Today and Tomorrow. In: Prosiding Persidangan Penterjemahan Antarabangsa ke-3. 27-29 August 1991. Kuala Lumpur: Dewan Bahasa dan Pustaka. 